\title{
Filozofia (badań) zarządzania. Rzecz o książce: Eric W. K. Tsang, The Philosophy of Management Research, Abington: Routledge 2017, ss. 233
}

DOI: http://dx.doi.org/10.12775/ZN.2019.004

Streszczenie. Nakładem wydawnictwa Routledge, tego samego, które opublikowało 25 tom z serii Praxiology (Gasparski [ed.] 2018), wydana została unikatowa książka The Philosophy of Management Research (Abingdon 2017) autorstwa Erica W. K. Tsanga, poświęcona filozoficznym aspektom badań z zakresu nauki o zarządzaniu. Książka jest unikatowa, ponieważ niewiele jest publikacji poświęconych tej problematyce pisanych z filozoficznego punktu widzenia, a przy tym dojrzałych naukowo. Sama zaś filozofia zarządzania w większości przypadków nie dotyczy filozofii jako dziedziny wiedzy, lecz „filozofii zarządzania” rozumianej jako ogólne rozważania o tym, jak prowadzić firmę. Tezy zaprezentowane w książce są pochodną analizy wyselekcjonowanych artykułów publikowanych w periodykach prezentujących wyniki badań zarządzania z uwzględnieniem ich metodologicznego ugruntowania. W związku z tym podejście Tsanga można uznać za swego rodzaju naukoznawstwo empiryczne.

Słowa kluczowe: badania zarządzania; epistemologia; filozofia zarządzania; metodologia; ontologia; teoria organizacji i zarządzania

\section{Philosophy of Management (Research). Thing about the Book: Eric W. K. Tsang, The Philosophy of Management Research, Abington: Routledge 2017, ss. 233}

\begin{abstract}
By the publication of Routledge the unique book The Philosophy of Management Research (Abingdon 2017) written by Eric W. K. Tsang was published. The book is devoted to the philosophical aspects of research in management science. The book is unique because there are few publications devoted to these issues written from a philosophical point of view, and at the same time scientifically mature. The management philosophy itself, in most cases, does not concern philosophy as a field of knowledge but "management philosophy" understood as general considerations on how to run a business. The theses presented in the book are a derivative of the analysis of selected articles published in periodicals presenting the results of management research with regard to their methodological grounding. Therefore, Tsang's approach can be considered as a contribution to the empirical science studies.
\end{abstract}

Keywords: epistemology; management philosophy; management research; methodology; ontology; organization and management theory 


\section{Wstęp}

W przedmowie autor pisze, że książka jest oparta na filozoficznej podstawie, na jakiej toczona jest debata dotycząca kluczowych kwestii metodologicznych, na które natrafiają badacze z nauk społecznych, w szczególności ci prowadzący badania nad zarządzaniem (s. VIII). Autor zauważa jednocześnie, że „zwykle filozofia nie jest rodzajem wiedzy, którą posiadają badacze zarządzania" (s. VIII). Sam nie kończył studiów filozoficznych. Wiedzę filozoficzną zdobył, interesując się nią hobbistycznie, a następnie - po zakończeniu współpracy z HSBC - na studiach doktoranckich w University of Cambridge. Zauważył on, że na studiach doktoranckich dla menedżerów głównie naucza się analizy statystycznej, a pomija logikę i filozofię. Sprawia to, że tak kształceni menedżerowie mają niedostateczną umiejętność argumentowania oraz wadliwie rozumieją niektóre zagadnienia metodologiczne. Przykładowo, zagadnienie replikacji, tj. kiedy trzeba, a kiedy nie powtórzyć dane badanie w celu zweryfikowania uzyskanych wyników i ich skontrolowania, natrafia na trudności. Jest to pochodną przekonań ontologicznych i epistemologicznych. Innego przykładu dostarcza traktowanie uogólniania jako problemu czysto statystycznego z pominięciem filozoficznego kontekstu (s. IX).

Tsang postanowił wpłynąć na istniejący stan rzeczy i wyruszył w podróż niemal dookoła świata, by prowadzić seminarium „Dlaczego badacze biznesu powinni studiować logikę i filozofię?". Seminarium to było oferowane szkołom biznesu w Australii, Japonii, Hongkongu, Chinach, Singapurze i Stanach Zjednoczonych. Autor odnotowuje, że niektórzy uczestnicy zajęć stwierdzili, że wprawdzie mieli możliwość zapoznania się z tekstami wprowadzającymi z zakresu filozofii zarządzania, to jednak było to niewystarczające mimo wskazywania źródeł literaturowych. Ta „skarga” dała początek książce. Autor wyraża nadzieję, że książka, dostarczając wiedzy z zakresu ogólnej metodologii badań naukowych, będzie przydatna nie tylko dla badaczy biznesu czy zarządzania, ale także innych dyscyplin z nauk społecznych (s. IX).

Książka, poza przedmową, składa się z ośmiu rozdziałów i załącznika oraz indeksów rzeczowego i osobowego. Niektóre z tych rozdziałów były wcześniej publikowane jako artykuły w periodykach naukowych w nieco innej postaci. Listę tych artykułów zamieszczono w książce. W dalszym ciągu tego artykułu omówione zostaną wybrane zagadnienia prezentowane w poszczególnych rozdziałach książki.

\section{Rozdział pierwszy - Filozofia: stużac pomoca badaczom}

Rozdział zaczyna się od stwierdzenia, że ekonomia, psychologia i socjologia są powszechnie uważane za dyscypliny macierzyste dla zarządzania, a filozofia 
jest postrzegana jako tajemniczy i trudny do zrozumienia przedmiot odległy od zarządzania. A przecież, pisze autor, „każdy badacz zarządzania uznaje świadomie lub nieświadomie jakąś filozofię" (s. 1). I rozwija tę myśl, wskazując, że filozofia wpływa dwojako na badania zarządzania: ontologicznie i epistemologicznie, badacze zarządzania bowiem uznają, że badane przedmioty są jakieś, a więc, że mają do czynienia $\mathrm{z}$ ontologią oraz że w jakiś sposób są one poznawalne, a więc, że występuje jakaś epistemologia. Obie, ontologia i epistemologia, wpływają na to, jakie metody są właściwe danym przypadkom badania. Ograniczanie metody li tylko do analizy statystycznej jest niewłaściwe bez uwzględnienia problemów metodologicznych, jakie rodzi jej stosowanie. Ważne są także przyjmowane założenia, nie chodzi przy tym jedynie o to, czy są one „realistyczne”, ponieważ takie nigdy nie są, lecz o to, czy stanowią dobrą aproksymację dla celu, w jakim badania są prowadzone - pisze autor i powołuje się na prace licznych autorów, które wskazuje w bogatej bibliografii.

Tsang zauważa, że wprawdzie $\mathrm{w}$ dziedzinie zarządzania nie prowadzi się tak wysublimowanych rozważań metodologicznych, to są pewne fragmenty tej dziedziny, w związku z którymi bierze się pod uwagę realistyczną ontologię. Dotyczy to głównie przedsiębiorczości, której istota jest głęboko zakorzeniona w filozofii. Sporne są jednak podejścia do badania przedsiębiorczości: jedno z nich oparte jest na empiryzmie i wskazuje odkrycie jako czynnik podstawowy, drugie zaś, określone jako aktualizacyjne, bazuje na realizmie.

W dalszym ciągu rozdziału Tsang porównuje główne perspektywy filozoficzne wyekstrahowane z przestudiowanych przezeń 50 artykułów opublikowanych w czołowych periodykach z zakresu nauki o zarządzaniu. Zapewne nie wyczerpują one punktów widzenia prezentowanych w literaturze o zarządzaniu, ale dostarczają podstaw do zarysowania mapy zagadnienia. Można uznać dzieło Tsanga za swego rodzaju empiryczne naukoznawstwo opisujące filozoficzne zagadnienia badań z zakresu nauki o zarządzaniu. Perspektywy te to: pozytywizm, postmodernizm, realizm krytyczny i pragmatyzm, a aspekty filozoficzne to: ontologia, epistemologia i metodologia. Autor zestawia cechy szczególne tych perspektyw i wyróżniających je aspektów w tablicy wskazującej różnice między podejściami. Przykładowo: pozytywistycznie zaangażowany badacz zakłada nieobciążoną (unbiased), a przy tym wolną od wartości innych niż ekonomiczne, metodologię i skłonny jest korzystać z metod ilościowych, takich jak pomiary (surveys), eksperymenty oraz analiza danych archiwalnych. Postmodernista kieruje się epistemologią uznającą wiedzę jako pochodną gier językowych, odrzuca metanarracje, pluralizm oraz fragmentację. Badacz kierujący się realizmem krytycznym stosuje ontologię wskazującą obiektywną, uwarstwioną rzeczywistość z domenami rzeczywistymi i empirycznymi, składającymi się ze struktur, mechanizmów i zdarzeń. Dodajmy jeszcze metodologię pragmatycznego badacza, który jest aktywnym uczestnikiem procesu transformacji i stosuje mieszane metody badań. 
Po scharakteryzowaniu perspektyw uprawiania badań zarządzania Tsang, powołując się na Johna Locke'a, określa filozofię jako pomocnika badacza. Spełnia ona tę funkcję przez demistyfikację eliminującą wadliwe założenia, niespójności oraz nieład; dostarcza informacji umożliwiających pełniejsze rozumienie postępowania badawczego; wskazuje metody i techniki badawcze lepiej dostosowane do przedmiotu badań.

Perspektywa filozoficzna reprezentuje światopogląd, na który składa się zbiór założeń i przekonań o naturze świata, i to, jak z nim współdziałamy oraz jak się o tym dowiadujemy. Te założenia i przekonania nie poddają się testowaniu empirycznemu w zwykłym rozumieniu tego terminu. Podobnie perspektywa filozoficzna nie jest ani weryfikowalna, ani falsyfikowalna. Nie znaczy to, że wybór perspektywy jest przedmiotem osobistego upodobania ani że nasza perspektywa jest lepsza od punktu widzenia innych. Perspektywa może być obiektywnie oceniana nie tylko ze względu na to, czy jest wewnętrznie spójna i dostarcza trafnego argumentu, ale także jak efektywnie odgrywa rolę służebną dla badacza (s. 9).

Autor kończy te rozważania informacją, że jest zwolennikiem realizmu krytycznego jako perspektywy najlepiej opracowanej i najpełniej służącej metodologią badaniom z zakresu zarządzania (s. 9).

\section{Rozdział drugi - Wyjaśnianie: różne sposoby odpowiadania na pytanie „dlaczego?”}

Autor rozpoczyna rozdział drugi od wskazania, że teorie naukowe odpowiadają raczej na pytanie o przyczynę, tj. „dlaczego?, a nie na pytanie o przedmiot, tj. „co?”. Dostarczają więc wyjaśnienia przyczynowego. Przyczynowość, pisze autor, powołując się na Petera Strawsona (1985), jest relacją występującą w naturze, tj. w świecie zdarzeń, natomiast wyjaśnianie jest relacją intelektualną, racjonalną lub intencjonalną. Wyjaśnianie, głównie w naukach przyrodniczych, wskazuje prawa, tj. wypowiedzi o postaci uniwersalnej warunkowej potwierdzonej lub zakwestionowanej przez stosowne odkrycia empiryczne (s. 19). Tsang powołuje się przy tym na Karla Hempla (1965). W naukach przyrodniczych zależności mają charakter deterministyczny, a w naukach społecznych, a więc i w nauce o zarządzaniu, zależności są natury probabilistycznej.

Autor opisuje kolejno wyjaśnianie mechanizmowe (mechanismic) w badaniach zarządzania, rolę kontekstu w tych badaniach, ważność znaczenia (Verstehen), wyjaśnianie kontrastowe (contrastive), fakty i tła (foil), korzyści, uogólnienia, wyjaśnienia ateoretyczne, niewyjaśnialne regularności empiryczne - wszystko w odniesieniu do badań zarządzania. 
Powołując się na Mario Bungego, który stwierdza, że ,żadne zdarzenie lub proces nie są uważane za zadowalająco zrozumiałe, chyba że zostanie ujawniony ich faktyczny lub możliwy mechanizm" (Bunge 1997), Tsang wskazuje, że mechanizm przyczynowy zwykle jest skonceptualizowany jako czarnoskrzynkowe zależności między wejściem i wyjściem przy braku możliwości identyfikacji tego mechanizmu ukrytego w owej czarnej skrzynce. W mechanizmowym wyjaśnianiu ważną rolę w badaniach dotyczących zarządzania odgrywa kontekst. Jest on związany z kulturą, zarówno narodową, jak i organizacyjną. Autor odnosi się do badań chińskich firm i dodaje, że ważnym aspektem jest interpretacyjne rozumienie $\left(\right.$ Verstehen $\left.^{1}\right)$.

Wyjaśnianie mechanizmowe jest obiecujące - stwierdza autor na zakończenie tego fragmentu rozdziału drugiego. Nie stanowi ono jednak panaceum na wszystkie problemy związane z empirycznym stanowieniem zależności przyczynowych (s. 24-25).

Wyjaśniane są nie zdarzenia, lecz aspekty zdarzeń brane pod uwagę ze względu na to, czym jesteśmy zainteresowani. W związku z tym stosuje się tzw. wyjaśnianie kontrastowe allomorficzne (wielopostaciowe) lub wyjaśnienie wykorzystujące fakty i ich tło $(f o i l)$. Co się tyczy wyjaśniania allomorficznego, to Tsang wskazuje je za Fredem Dretskim (1977), który allomorfami nazwał wyrażenia różniące się wyróżnionymi aspektami będącymi przedmiotem zainteresowania badacza. Oto przykład stwierdzenia (niewystępujący w książce, lecz ilustrujący znaczenie terminu):

Stwierdzenie S:

allomorf pierwszy $\mathrm{S}_{1}$ allomorf drugi $\mathrm{S}_{2}$ allomorf trzeci $\mathrm{S}_{3}$ allomorf czwarty $\mathrm{S}_{4}$
Uczelnia kształci studentów zarządzania. Uczelnia kształci studentów zarządzania. Uczelnia kształci studentów zarządzania. Uczelnia kształci studentów zarządzania. Uczelnia kształci studentów zarządzania.

Każdy z allomorfów wskazuje inny aspekt zdarzenia i sugeruje inny zestaw pytań, na jakie w badaniach poszukuje się odpowiedzi w celu wyjaśnienia tego,

\footnotetext{
1 Verstehen „w kontekście niemieckiej filozofii i nauk społecznych, jest używany od końca XIX wieku - w języku angielskim i niemieckim - ze szczególnym uwzględnieniem »interpretacyjnych lub partycypacyjnych« badań zjawisk społecznych. Termin ten jest ściśle związany z pracą niemieckiego socjologa Maxa Webera, którego antypozytywizm stanowił alternatywę dla wcześniejszego pozytywizmu socjologicznego i determinizmu gospodarczego, zakorzenionych w analizie działan społecznych. W antropologii Verstehen oznaczał systematyczny proces interpretacyjny, w którym zewnętrzny obserwator kultury próbuje się do niej odnieść i zrozumieć innych. Verstehen jest teraz postrzegany jako koncepcja i metoda kluczowa dla odrzucenia pozytywistycznej nauki społecznej. Verstehen odnosi się do zrozumienia znaczenia działania z punktu widzenia aktora. Wchodzi w rolę drugiego, a przyjęcie tej postawy badawczej wymaga traktowania aktora jako podmiotu, a nie przedmiotu obserwacji. Oznacza to również, że w przeciwieństwie do obiektów w świecie przyrody, aktorzy ludzcy nie są jedynie produktem przyciągania i popychania sił zewnętrznych. Jednostki są postrzegane jako tworzące świat, organizując własne rozumienie go i nadając mu sens. Prowadzenie badań nad aktorami bez uwzględnienia znaczenia, jakie przypisują swoim działaniom lub środowisku, sprawia, że są traktowani jak przedmioty", https://www.definitions.net/definition/verstehen (dostęp: 1.08.2019).
} 
co interesuje badacza. Im właściwsze pytania, tym w większym stopniu odpowiedzi dostarczają wiedzy umożliwiającej wykonywanie odpowiednich działań. Zauważmy przy okazji, że pośrednio Tsang sugeruje, iż badania zarządzania, czyli nauka o zarządzaniu (management science), są nauką praktyczną, choć nigdzie o tym w książce nie wspomina. Nie nawiązuje także do nauki o artefaktach (sciences of the artificial) Herberta A. Simona.

Kanoniczną formą pytań kontrastowych jest „Dlaczego raczej P niż Q?”, gdzie P jest faktem oczekującym wyjaśnienia, Q zaś tłem, alternatywą w stosunku do faktu, przy czym może być albo jednostkowym zastępnikiem, albo zbiorem możliwych zastępników. Takie postawienie sprawy wskazuje, że nie jest możliwe równoczesne występowanie P i Q. Autor omawia w związku z tym przykłady zastosowań zaczerpnięte z niektórych przestudiowanych przezeń artykułów.

W następnej kolejności omawia on zagadnienie stopnia ogólności wyjaśnień w badaniach zarządzania. Odnotowuje występowanie w literaturze z zakresu zarządzania trzech typów wyjaśniania. Pierwszy typ zawiera nieliczne ograniczenia przestrzenno-czasowe, wyjaśnienie zaś dotyczy szerokiego zakresu zastosowań. Przykładowo takim typem jest poszukiwanie wyjaśnienia w związku z pytaniem „Dlaczego jest tu tyle rodzajów organizacji?”. Drugi typ wyjaśnienia ma wyraźnie określone granice przestrzenno-czasowe, np., gdy analizuje się „500 firm w okresie od 1966 do 2003 roku” ze względu na jakąś prawidłowość. Trzecim rodzajem wyjaśnienia są zagadnienia dotyczące wyodrębnionych zdarzeń. Do nich mają zastosowania studia przypadków.

Tsang wskazuje następnie na wyjaśnienia a te or etyczne. Nie odwołują się one do jakiejś teorii ani nie zamierzają żadnej budować. Za przykład może służyć poszukiwanie przez menedżerów nadprzyrodzonych źródeł informacji, mają podjąć strategiczne decyzje, np. korzystanie z usług wróżbitów oraz modlenie się do bożków. Takie fakty są odnotowywane i nad nimi Tsang przeprowadził badania w Hongkongu i Singapurze (Tsang 2004). Były to badania eksploracyjne, a więc nieodwołujące się do jakiejś teorii ani jej nietworzące. Autor narzeka jednak, że periodyki akademickie nie chcą przyjmować prac tego rodzaju. A przecież ateoretyczne wyjaśnienia są wyjaśnieniami, stwierdza autor książki i jako ostatnie zagadnienie omawiane w tym rozdziale wskazuje tzw. ni ew y jaśni one re gularności empiryczne. Zauważa, że występują one także w naukach ścisłych. Jako przykład podaje odkrycie w roku 1928 penicyliny przez Aleksandra Fleminga, co przyczyniło się do uratowania wielu ludzi w czasie II wojny światowej, chociaż molekularną strukturę tego specyfiku odkryto dopiero w roku 1945. Dokonała tego Dorothy Mary Crowfoot Hodgkin, a mechanizm generatywny efektu ozdrowieńczego został poznany jeszcze później (Lax 2004).

Jak wskazują obserwacje, w empirii występują pewne niezmienniki odnoszące się do świata społecznego. Tsang, powołując się na Tony'ego Lawsona (1997), określa to jako połowiczną regularność (demi regularity) świadczącą o tym, że 
od czasu do czasu, ale nie stale, mogą wystąpić pewne tendencje albo zjawiska. Przykładem jest krzywa uczenia się. Nauki społeczne mają za zadanie identyfikować regularności w badanych przez nie dziedzinach i poszukiwać ich wyjaśnienia. Autor w konkluzji stwierdza, że „,badanie naukowe realizuje postęp w trzech stadiach: odkrywanie empirycznych regularności, konstruowanie wyjaśnień i tworzenie teorii" (s. 32).

\section{Rozdział trzeci - Założenia: czyli nie to, co można pominać}

„Każda teoria bazuje na jakichś założeniach” (s. 38) - tak brzmi pierwsze zdanie tego rozdziału, a po nim Tsang przytacza wypowiedź Miltona Friedmana (1953), że teorie ekonomiczne powinny być krytykowane za przyjmowanie nierealistycznych założeń, oceniane zaś za trafność przewidywań. Tsang odnotowuje, że badacze zarządzania, z nielicznymi wyjątkami, rzadko przywiązują wagę do roli odgrywanej przez założenia. Autor postawił sobie dwa cele do osiągnięcia w tym rozdziale: po pierwsze, przedyskutowanie relacji między założeniami a wyjaśnianiem, po drugie, rozróżnienie między dwoma sposobami testowania teorii: (a) z pominięciem założeń, (b) z uwzględnieniem założeń. Tsang zauważa, że ,gdy nowa teoria jest na początku testowana, ten drugi sposób znaczy więcej aniżeli pierwszy" (s. 38).

Autor książki, powołując się na literaturę przedmiotu, stwierdza, że założenia użytecznych teorii nie muszą być realistyczne. Przykładem jest dylemat więźnia, w którym więźniowe i policjanci są użyci metaforycznie, a nie sprawozdawczo. Tsang powtarza za Ernestem Naglem (1963), że założenie, które nie dostarcza dokładnego opisu pewnego stanu rzeczy, jest nierealistyczne. Założenie jest również nierealistyczne, jeśli jest fałszywe lub wysoce nieprawdopodobne. Należy dodać, że teorie są idealizacjami dotyczącymi bytów nieistniejących w świecie realnym. Istotne dla budowy teorii jest to, w jaki sposób założenia zdają sprawę z relacji zachodzących między elementami badanego zjawiska. Wyróżnić można następujące rodzaje postawy wobec założeń: zaniedbanie, określenie dziedziny, heurystykę. $\mathrm{Z}$ zaniedbaniem mamy do czynienia, gdy pomija się efekt lub czynnik związany z badanym zjawiskiem; w drugim przypadku wskazuje się dziedzinę występowania zjawiska badanego; trzeci rodzaj wspomaga rozwijanie teorii. Pośród założeń rozróżnia się założenia podstawowe i uboczne (s. 39-41). Założenia nierealistyczne prowadzą do nierealistycznego wyjaśniania, niezbędny jest przeto realizm założeń.

Warto przypomnieć w tym miejscu wypowiedź Herberta A. Simona wygłoszoną na warszawskiej konferencji „Praxiologies and the Philosophy of Economics" (1988): 
W empirycznej literaturze klasycznej ekonomii można zauważyć uderzający brak dowodów na dążenie do optymalizacji, które byłyby oparte na bezpośredniej obserwacji zachowania podmiotów ekonomicznych. Milton Friedman usiłował w swym słynnym eseju o metodologii ekonomii uczynić z tego niedostatku cnotę. Dowodzi on, że teorii nie można osądzać na podstawie realizmu jej założeń, lecz na podstawie zasadności opartych na niej przewidywań. [...] Drugą wadą dowodów Friedmana jest twierdzenie, że nierealność założeń nie jest naganna lub przynajmniej jest to możliwe do przyjęcia. [...] Żaden ze znanych mi systemów logiki ani też żadna ze szkół filozofii nauki nie dostarcza poparcia dla Friedmanowskiej zasady nierealizmu (Simon 1989, s. 142-143).

Tsang przedstawia związek założeń i wyjaśnienia na podstawie badań dotyczących ekonomii kosztów transakcyjnych (s. 43-50). A na zakończenie rozważań stwierdza, że „Chociaż subiektywne i obiektywne koszty transakcyjne są silnie skorelowane, to studia oparte na, powiedzmy, podejściu menadżerskim mierzącym koszty transakcyjne w sposób obiektywny mogą prowadzić do błędnych wyników" (s. 50).

Kolejnym zagadnieniem omawianym w tym rozdziale jest porównanie testowania teorii opartych na założeniach i teorii pomijających je. Celem testowania teorii jest badanie, w jakim stopniu proponowany przez teorię mechanizm jest zgodny z obserwowanymi zdarzeniami. Gdy podczas budowania teorii uwzględnia się założenia, to bada się empirycznie ich występowanie we wstępnej fazie tworzenia teorii. W badaniu chodzi o stwierdzenie siły wpływu tego, co jest zakładane, na badane zjawisko. Konkludując, autor stwierdza, że

główne założenia teorii (core assumptions) często dotyczą podstawowego zagadnienia ludzkiej natury. Dokładniej: założenia te konstytuują podstawę wyjaśnienia przez teorię mechanizmu i odgrywają kluczową rolę w jej opracowaniu. Nierealistyczne założenia prowadzą do nierealistycznych wyjaśnień i wadliwej teorii. Stopień realistyczności założeń powinien być stwierdzony empirycznie. [...] gdy projektuje się test empiryczny do zbadania nowej teorii, badacze powinni pytać, „Czy mimowolnie nie przyjęliśmy podstawowych założeń teorii jako coś tak oczywistego, że pominęliśmy je?" (s. 55-56).

\section{Rozdział czwarty - Testowanie teorii: pozornie prosty proces}

Rozdział czwarty rozpoczyna się od konstatacji, że większość programów studiów doktoranckich dla menedżerów naucza metody statystycznego testowania hipotezy zerowej (null hypothesis statistical testing - NHST) stosowanej do testowania hipotezy (i potwierdzającej ją teorii) i sprawdza, czy ów zerowy odpowiednik można odrzucić jako pewien poziom istotności (zwykle $\mathrm{p}<0,05)$. Autor dodaje: „Co ważniejsze, [doktoranci - W. W. G.] rzadko są informowani o komplikacjach związanych z tym pozornie prostym sposobem testowania teorii” (s. 63). Przyto- 
czona konstatacja służy Tsangowi do wskazania, że NHST jest jednym z aspektów szerszego problemu filozoficznego z zakresu testowania teorii. „Ten wadliwy sposób testowania teorii - któremu towarzyszy kilka prób falsyfikacji - prowadzi do proliferacji teorii zarządzania” - zauważa autor i dodaje, że „Obecność różnorodnych, a nawet sprzecznych teorii powoduje zamieszanie zarówno pojęciowe, jak i dotyczące praktyki zarządzania" (s. 63).

Na ogół teorie dotyczące zarządzania nie są ani potwierdzane, ani odrzucane; po prostu „są zawieszone” w przestrzeni teoretycznej. Na dowód Tsang przytacza słowa Harolda Koontza (1961) o „dżungli teoretycznej w zarządzaniu”. Podobnie wypowiadał się Henry Mintzberg (Mintzberg, Ahlstrand, Lampel 1998), a Jefferey Pfeffer napisał, że dziedzina teorii organizacji „bardziej przypomina gąszcz chwastów niż zadbany ogród" (Pfeffer 1982). Tymczasem w filozoficznej dyskusji nad metodami naukowymi zwraca się uwagę na znaczącą rolę falsyfikacji w rozwoju teorii (Popper 1959). Według autora, jeśli teoria zarządzania nie będzie falsyfikowalna, to jej naukowy status będzie zagrożony. W związku z tym Tsang zestawia weryfikację i falsyfikację teorii, kładąc nacisk na tę drugą. Chce w ten sposób wywrzeć wpływ na praktykę badaczy zarządzania i skłonić ich do tego, by starali się zachować równowagę między oboma rodzajami testowania tworzonych przez nich teorii zarządzania, co ma doprowadzić do większego rygoru w tworzeniu tych teorii.

W dalszej części rozdziału autor omawia przeszkody stojące na drodze do rygorystycznego testowania teorii: istotę zjawisk społecznych, kwestię teoretyzowania, tezę Duhema-Quine’a, zagadnienie niewspółmierności teorii oraz zachęty profesjonalne.

O zjawiskach społecznych autor mówi, że są to systemy otwarte i nierealistyczne jest zakładanie, że wszystkie odnoszące się do nich dane będą zgodne $\mathrm{z}$ teorią, nawet wtedy, gdy jest poprawna. Organizacja bowiem jest tworem złożonym i zmieniającym się. Teorie opisujące organizacje dotyczą różnych jej aspektów. Nie jesteśmy w stanie zidentyfikować wszystkich zmiennych i sformułować hipotezy o występujących zależnościach. $\mathrm{Z}$ tego względu teorie traktowane są nie jako konkurencyjne, lecz raczej jako komplementarne. Tym różni się testowanie teorii w naukach społecznych od testowania w naukach przyrodniczych. Ponadto trudnością związaną z rygorystycznym testowaniem konkurujących teorii w naukach społecznych jest występowanie czynnika wolicjonalnego, jako ludzie dysponujemy bowiem swobodą działania. Wolna wola i twórczość ograniczają predyktywną moc teorii. Co więcej, sama aktywność badawcza może wpłynąć na zachowania menedżerów, zakłócając ciągłość badanych zjawisk. Badacze mogą być również katalizatorami zmian $\mathrm{w}$ organizacji, jeśli podważają odpowiedniość zalecanych zmian.

Trudność falsyfikowania teorii dotyczących zarządzania wynika z niskiego stopnia ich precyzji. W naukach przyrodniczych uważa się, że istnieje tylko jedna 
poprawna teoria opisująca zjawisko. W naukach społecznych w ogóle, a w nauce o zarządzaniu w szczególności, mamy do czynienia z wielością teorii. Wieloteoriowe (multi-theoretic) podejście dostarcza pełniejszej (more holistic) perspektywy. Dlatego taki periodyk jak Academy of Mangement Review, publikujący jedynie artykuły twórcze, tj. oryginalne, wskazuje w nocie redakcyjnej, że „potrzeba opracowywania wyjaśnień dotyczących wielu punktów widzenia w dziedzinie zarządzania stale rośnie"2 (Okhuysen, Bonardi 2011, s. 6). Oceniając dodatnio to podejście, Tsang stwierdza, że jest ono korzystne ze względu na złożoność organizacji i brak ogólnej teorii prezentującej rozmaitość zjawisk organizacyjnych. Natomiast podchodząc do tego krytycznie, należy stwierdzić, że może to świadczyć o niepowodzeniu dokładnego sprecyzowania i analizy założeń, wyjaśnienia oraz implikacji przez różne teorie w celu ustalenia, czy są one zgodne lub niezgodne (s. 69).

Co się tyczy badań empirycznych związanych z zarządzaniem, to wykorzystywane w nich teorie menadżerskie, jak nazywa je Tsang, nie dostarczają informacji, czy wskazują one wyraźnie, jak szczegółowe są stosowane przez nie modele. Podawane są przyczyny i efekty, ale nie opóźnienia. Większość teorii opisuje systemy otwarte, a nie zamknięte. $Z$ tego powodu nieuwzględniane bywają relacje interesujące z punktu widzenia innych zdarzeń, co prowadzi do mylnych rozwiązań.

Badacze skłonni są przyjmować „pozytywną strategię testową” przy badaniu przypadków, dla których tworzona jest teoria. „Badacz dla uzyskania zgodności z teorią modyfikuje procedury, aż uzyska wyniki wspierające przewidywanie" (s. 70-71). Autor przedstawia także inne sposoby spotykane w badaniach empirycznych. A na zakończenie podrozdziału stwierdza, że „badacze zamierzający znaleźć efekt, jaki przewiduje teoria, mogą zrobić wszystko, aby osiągnąć wyniki danych empirycznych poprzez »masowanie« danych" (s. 70-71). Jako przykład oportunizmu badaczy podaje, iż „mogą oni brać udział w wyszukiwaniu specyfikacji modelu, usuwając obserwacje $\mathrm{w}$ taki sposób, aby poprawić dopasowanie modelu i osiągnąć statystycznie istotny współczynnik zgody z oczekiwaniami” (s. 72).

W kolejnym podrozdziale Tsang zwraca uwagę na tzw. tezę Duhema-Quine’a. Jest to koncepcja znana w filozofii nauki, dotycząca zależności pomiędzy danymi empirycznymi a teorią naukową.

Według tezy Duhema-Quine’a dane empiryczne nie określają jednoznacznie teorii naukowej. Zbiór wszystkich danych doświadczalnych jest skończony, a więc do takiego zbioru można zawsze (przynajmniej potencjalnie) dopasować nieskończenie wiele różnych teorii. Laudan precyzuje tezę Duhema-Quine’a w następujący sposób: Dla dowolnej teorii $\mathrm{T}$ i dowolnego zbioru dowodów $\mathrm{S}$ potwierdzających teorię $\mathrm{T}$ istnieje konkurencyjna dla teorii $\mathrm{T}$ (i sprzeczna z teorią T) teoria $\mathrm{T}^{\prime}$, taka, że zbiór dowo-

2 Tłumaczenia cytatów pochodzą od autora recenzji. 
dów S potwierdza teorię $\mathrm{T}^{\prime}$. Termin w szczególności obejmuje koncepcje, że obserwacje empiryczne zawsze są obciążone dodatkowymi założeniami teoretycznymi. $Z$ tego powodu treść empiryczna przysługuje całym systemom zdań, całej teorii lub nawet całej nauce, a nie poszczególnym jej elementom w postaci konkretnych zdań obserwacyjnych ${ }^{3}$.

Jako przykład autor rozważa badania z zakresu Total Quality Management (TQM). Pisze on:

Załóżmy, że naukowiec stwierdził, iż wbrew teorii TQM miał negatywny wpływ na produktywność. Badacz nie może po prostu stwierdzić, że teoria została sfalsyfikowana. Dostosowanie hipotez pomocniczych może umożliwić pozostawienie teorii bez zmian. Ten problem ostatecznego ustalania postaci teorii jest szczególnie poważny w naukach społecznych, w których naukowcy nie są zgodni co do tego, w jaki sposób niektóre hipotezy pomocnicze powinny być niezależnie testowane (s. 73).

Niewspółmierność teorii to kolejne zagadnienie, któremu Tsang poświęca uwagę. Zauważmy w tym miejscu, że autor książki korzysta z licznych źródeł, przywołując bogatą literaturę do tematów poruszanych w poszczególnych podrozdziałach. W tym podrozdziale odwołuje się do pracy Lexa Donaldsona (1995), za którym odnotowuje, że teorie zarządzania są sformułowane w rozmaitych językach i wsparte licznymi metodologiami, ponieważ dotyczą różnych analiz i wartościowań organizacji oraz menedżerów (s. 73). Badacze zarządzania tworzący te teorie ograniczeni są niszami, w jakich pracują, co utrudnia komunikowanie się i powoduje zamknięcie się we własnym kręgu teoretyzowania. Teorie stają się niewspółmierne. Utrudnia to ich testowanie, tak że stają się one „luźną i efektowną modą” (s. 73). „Ogólnie rzecz biorąc - pisze Tsang - niewspółmierność odnosi się do jednostkowej kwalifikowalności teorii dla osób postronnych z powodu ogólnych założeń (np. ontologii i epistemologii) i słownictwa (tj. braku neutralnego języka obserwacji)" (s. 73). Niemożliwe staje się komunikowanie między teoriami, co przekreśla wzajemne konkurowanie takich teorii. Stają się one nieporównywalne. Autor książki nie wypowiada się w sprawie prawdziwości tego rodzaju teorii zarządzania, zwraca natomiast uwagę na tzw. zachęty zawodowe. Zachęty te to pozytywne recenzje artykułów prezentujących daną teorię, przyczyniają się do jej upowszechnienia, co powoduje wzrost cytowań. Tsang pisze, że analiza kosztów i strat zachęca twórców teorii do preferowania raczej weryfikacji, a nie falsyfikacji stworzonych przez nich teorii. Osłabia to stwierdzenie prawomocności proponowanych teorii (s. 75).

3 https://pl.wikipedia.org/wiki/Teza_Duhema-Quine'a (dostęp: 5.08.2019) 
Dalsza, obszerna, część rozdziału poświęcona jest metodom testowania teorii. Powołując się na Roya Bhaskara (1978), autor książki zwraca uwagę na to, że większość badaczy kieruje się ontologią e mpiry czną, która łączy się z empirią i realnością, a nie ontologią realistyczną. Badają oni raczej regularności empiryczne opisywane jako zależności korelacyjne, nie zaś zależności przyczynowe. Autor stara się wypełnić lukę w dostępie do wiedzy o testowaniu teorii menedżerskich z perspektywy krytycznego realizmu. Proponuje on czterokrokowe podejście do testowana oraz przedstawia projektowanie programów badawczych. Owe cztery kroki to:

1. Identyfikacja mechanizmu przyczynowego, który - jak się uważa - tłumaczy hipotetyczne relacje w badaniu. Ten krok wymaga pracy interpretacyjnej na styku teorii i empirycznego kontekstu tego, co jest przedmiotem zainteresowania.

2. Rozważenie, czy proponowane mechanizmy są rzeczywiście obecne w otoczeniu empirycznym. Wymaga to uzasadnienia istnienia mechanizmów przyczynowych.

3. Jeśli dostępne dowody potwierdzą obecność teoretycznych mechanizmów, można przejść do testowania ich skutków przyczynowych. Przed próbą zweryfikowania lub sfalsyfikowania całego systemu teoretycznego w otwartym kontekście należy jako zabezpieczenie wykonać testowanie binarnych lub bardziej złożonych podzbiorów relacji zachodzących w kontrolowanych okolicznościach.

4. Jeśli dane empiryczne potwierdzają mechanizmy teorii i ich skutki, następnym krokiem jest wspólne zbadanie implikacji jej mechanizmów. Ten krok przenosi analizę z izolowanych mechanizmów na cały system teoretyczny, tym samym zwiększa złożoność procedury oceny (s. 77-81).

W dalszej części rozdziału mowa jest o tym, jak poszczególne projekty badań wpływają na testowanie teorii. Realizm krytyczny ma charakter pluralistyczny, tj. umożliwia posługiwanie się wieloma metodami w badaniach empirycznych. Tsang rozróżnia projektowanie ekstensywne i intensywne. Projekty pierwszego rodzaju koncentrują się wokół: (1) korelacji empirycznych, zamiast skupić się na określaniu mechanizmów wyjaśniających, (2) założeń stabilności i zamknięcia modelu, (3) statystycznych testów istotności. Projekty drugiego rodzaju uzupełniają projekty ekstensywne w ten sposób, że odnoszą je do występujących między przypadkami różnic, których można by oczekiwać, gdyby wyniki empiryczne wynikały z połączenia wielu mechanizmów w systemach otwartych. Projekty te mają na celu identyfikację i opis mechanizmów generatywnych działających w konkretnej sytuacji, co często jest wykonalne w przypadku projektów ekstensywnych (s. 82-83). W badaniach korzysta się z hipotez pomocniczych. Testowanie tych hipotez jest omówione w osobnym podrozdziale, w którym Tsang nawiązuje do wcześniej opisanej tezy Duhema-Quine’a. 
Rozdział zamykają rozważania nad tzw. testami krytycznymi, których zadaniem jest osądzenie relatywnych zasług konkurujących teorii. Poszukuje się argumentu przesądzającego o prawomocności którychś z rywalizujących ze sobą propozycji teoretycznych. W tym celu testuje się mechanizmy wyjaśniające tych teorii bądź ich sprzeczne implikacje (s. 85). Podsumowując rozdział, autor stwierdza, że w dziedzinie zarządzania rywalizujące między sobą teorie wskazują wartość praktyczną różniących się przekonań. Silną stroną tych teorii jest ich interdyscyplinarny charakter i wielopostaciowość organizacji. „Problemem jest - pisze autor - nie wielość teorii, ale to, że zbyt rzadko, jeśli w ogóle, niektóre eliminujemy" (s. 86).

\section{Rozdział piąty - Uogólnienie: kontrowersyjne przedsięwzięcie}

Głównym celem nauk społecznych, pisze Tsang, jest wyjaśnianie i formułowanie uogólnień dotyczących życia społecznego ${ }^{4}$. W odniesieniu do badań zarządzania Mintzberg stwierdził, że „Jeśli nie ma uogólnienia poza danymi, to nie ma teorii. Nie ma teorii, to nie ma wglądu. A jeśli nie ma wglądu, to po co badania?" (Mintzberg 2005, s. 361). Rozdział piąty służy, po pierwsze, zdefiniowaniu generalizacji oraz klasyfikacji indukcji, po drugie, eliminacji nieporozumień dotyczących uogólnień, po trzecie wreszcie, obaleniu dominującego poglądu, że studia przypadków w niewielkim stopniu nadają się do uogólnień na ich podstawie. Tsang wyjaśnia, że skupia się na metodologii studiów przypadku, ponieważ inne badania jakościowe, np. etnograficzne, rzadko są stosowane w badaniach zarządzania (s. 99).

Definiując studium przypadku, Tsang powołuje się na pracę Roberta K. Yina, za którym przytacza następującą definicję: case study to „badanie empiryczne, które bada dogłębnie współczesne zjawisko (case) w kontekście realnego świata, zwłaszcza gdy granice między zjawiskiem a kontekstem mogą nie być wyraźnie widoczne” (Yin 2014, s. 16). Natomiast uogólnienie (generalizacja) to „ogólne stwierdzenie lub twierdzenie wywiedzione z obserwacji czegoś szczegółowego" (Schwand 1997, s. 57). Uogólnienie jest czasem mylone z indukcją, która ma szersze znaczenie. Uogólnienie oznacza wnioskowanie kierunkowe prowadzące od czegoś szczegółowego do czegoś ogólnego, indukcja zaś prowadzi od przesłanki szczegółowej do szczegółowej konkluzji, która nie jest uogólnieniem. Autor wymienia następujące rodzaje indukcji oraz odpowiadające im rodzaje generalizacji (uogólnień): uogólnienie teoretyczne, tj. od badań do teorii; uogólnienie p opulacyjne, tj. od tego, co jednostkowe, do tego, co dotyczy całej populacji; uogólnienie międzypopulacyjne,tj. od tego, co dotyczy jednej popula-

4 Autor powołuje się na prace: Danermark i in. 2002; Hägg, Hedlund 1979. 
cji, do tego, co dotyczy zbioru populacji; uogólniennie kontekstowe, tj. od tego, co dotyczy próbki z jednej populacji, do tego, co dotyczy członków innej populacji przy różnych kontekstach, ale podobnym czasie występowania; u o g ólnien ie czasowe, tj. od tego, co dotyczy próbki z jednej populacji, do tego, co dotyczy innych członków tej samej lub innej populacji w różnym czasie przy analogicznych kontekstach; sylogizm staty styczny, tj. przy przesłance szczegółowej wyrażonej procentowo; analogia indukcyjna, tj. przy określeniu przesłanek jako własności wskazanych podmiotów (s. 102).

Tsang uważa, że przedstawiona klasyfikacja ułatwia badaczom zarządzania wskazywanie ograniczeń odnoszących się do ich badań (s. 106). Natomiast filozofia dostarcza wglądu w to, co wnoszą badania prowadzone z pozytywistycznego punktu widzenia w porównaniu z interpretywizmem oraz realizmem krytycznym (s. 107). Uogólnienie może mieć charakter teoretyczny bądź empiryczny. Empiryczna generalizacja dotyczy tego, czy uzyskane wyniki są typowe dla populacji, z której pochodzą badane przypadki, czy może dla innej zbiorowości. Teoretyczna generalizacja zdaje sprawę z wkładu wyników uzyskanych w badaniach przypadków wnoszonego do teorii, która wedle realizmu krytycznego ma postulowaną strukturę i mechanizmy funkcjonujące $\mathrm{w}$ wyodrębnionym fragmencie rzeczywistości (real domain). Badacze formułują wyjaśnienia relacji między zmiennymi obserwowanymi w badaniach przypadków (s. 109). Rozważania nad uogólnieniami Tsang uzupełnia omówieniem błędnych generalizacji zawinionych przez ich błędne rozumienie, nieprzestrzeganie podstawowych zasad filozoficznych oraz niespójności logiczne (s. 110-115). Rozdział zamyka wskazanie korzyści płynących z badania przypadków. Są to: budowanie i testowanie teorii oraz identyfikacja prawidłowości empirycznych. „Innymi słowy - pisze autor - budowanie teorii jest warunkiem wstępnym testowania teorii, ponieważ bez teorii nie byłoby czego testować. Jednocześnie wyniki testowania teorii wzmacniają lub osłabiają empiryczną podstawę teorii, a nawet mogą ją obalić" (s. 122).

\section{Rozdział szósty - Replikacja*: zignorowana konieczność}

Tsang, cytując Geoffa Cumminga, pisze, że „Replikacja tkwi w samym sercu nauki” (Cumming 2008, s. 286). Służy ona jako „rozgraniczenie między nauką a nienauką" (Brande 1979, s. 42). Inny uczony i uznany statystyk, John Ashworth

\footnotetext{
„Replikacja to pojęcie z zakresu metodologii nauk oraz statystyki opisujące powtarzanie badań w celu zweryfikowania ich wyników jako część ustawicznego procesu autokorekcyjnego w metodzie naukowej. Słowami filozofa nauki Karla Poppera [powiemy - W. W. G.] »niepowtarzalne, jednostkowe wydarzenia nie mają dla nauki żadnego znaczenia« [Popper 1977, s. 74]. Statystyk Ronald Fisher napisał: »możemy uznać, że zjawisko jest udowodnione eksperymentalnie wówczas, gdy wiemy, jak przeprowadzić eksperyment, który rzadko zawiedzie w wykazaniu istotnych statystycznie rezultatów«" (Fisher 1974, s. 14, za: https://pl.wikipedia.org/ wiki/Replikacja_(metoda_naukowa); dostęp: 15.08.2019).
} 
Nelder, zauważa, iż „naukowiec zaczyna wierzyć, że odnosi sukces wówczas, gdy uzyskuje replikowalne wyniki z kilkunastu eksperymentów przeprowadzonych w różnych warunkach, stosując różne instrumenty, i to w różnych miejscach itd." (Nelder 1986, s. 113). W naukach przyrodniczych replikacja jest powszechną praktyką, w naukach społecznych zaś przeciwnie - jest ona rzadko stosowana, w szczególności dotyczy to badań zarządzania (129). Tsang zestawił w tablicy 14 przykładów badań w - jak to nazywa - dyscyplinach biznesowych (s. 130-131). $\mathrm{Z}$ zestawienia tego widać, że rezultaty uzyskane w badaniach powtórzonych (replikacje) w większości przypadków nie zgadzały się z wynikami oryginalnymi, a w najlepszym przypadku potwierdzały je tylko częściowo. Autor zauważa, że badacze zarządzania niekiedy akceptują dwuznaczne wyniki przeprowadzonych przez siebie badań. Apele o wykonywanie replikacji nie znajdują posłuchu, jakby „padały na głuche uszy” (s. 132) - pisze autor.

Jako przyczyny niskiego udziału prac zdających sprawę z replikowanych badań zarządzania autor książki wskazuje politykę redakcyjną czasopism. Jedynie cztery redakcje spośród 79 zapytanych odpowiedziało, że replikacja mieści się w ich praktyce redakcyjnej. Pozostali wolą publikować nowinki, zniechęcając nawet do replikacji. Tsang dodaje, że „Obsesja i redaktorów czasopism o zarządzaniu, i autorów ukierunkowująca na »interesujące« teorie i »nieintuicyjne« odkrycia jest bezpodstawna, ponieważ takie atrybuty mają niewielkie znaczenie epistemiczne. [...] Głębszy filozoficzny powód niedostatku replikacji może być związany z tym, jak naukowcy rozumieją naturę nauki” (s. 133). Tsang pyta, czy replikacja jest w ogóle możliwa w naukach społecznych. Odpowiedź nie jest jednoznaczna i budzi kontrowersje. W związku z tym dobrze jest wskazać rodzaje replikacji. Tsang rozróżnia trzy jej rodzaje: (1) sprawdzenie analizy - przy tych samych danych sprawdza się wnioskowanie; (2) dokładna replikacja - przy tej samej populacji przeprowadza się rozszerzenie koncepcji; (3) empiryczna generalizacja - przy innej populacji dokonuje się uogólnienia rozszerzającego (s. 138-145).

„Chociaż replikacje nie prowadzą do ostatecznej weryfikacji lub falsyfikacji teorii, to pomagają wspierać lub dyskredytować teorie" (s. 145). Prowadzą do lepszego dostosowania teorii oraz do bardziej poprawnego przewidywania zdarzeń; umożliwiają weryfikację bądź falsyfikację teorii. Są one jednak ograniczone. Wprawdzie wskazują błędy popełnione w badaniach oryginalnych oraz to, w jakim stopniu badania te były niezawodne, zwiększają wiarygodność przewidywań, rzucają nowe światło na struktury, mechanizmy i warunki brane pod uwagę w badaniach oryginalnych, stwarzają możliwość powtarzania złych badań, to jednak niewielkie jest prawdopodobieństwo tworzenia przez nie nowych teorii i są postrzegane jako mało twórcze. W związku z tym postrzega się badania innowacyjne jako oferujące nowe pojęcia, rozszerzające zakres badań, pobudzające do tworzenia nowych teorii, ale oparte na słabej ewidencji empirycznej (s. 149). 
Nauka o zarządzaniu, w przeciwieństwie do nauk społecznych, nie stanowi spójnego korpusu wiedzy. Wydaje się, że zwiększenie replikacji badań z zakresu zarządzania mogłoby przyczynić się do poszerzenia tego korpusu, jak sądzi autor omawianej książki. Konstatuje on, że badania empiryczne tworzące rozproszony wzór (scattered pattern) są rzadko replikowane, a różnią się metodami badawczymi, sposobami pomiaru, definicjami, populacjami przedmiotów badanych, istotą badanych zjawisk itd. Tsang pisze, że empiryczny korpus wiedzy utworzony na podstawie tego wzoru zawiera wiedzę fragmentaryczną, ,,porozrzucane kawałki" (s. 151). Brak replikacji prowadzi do powstawania rozdrobnionej literatury, czego nie warto powtarzać. Nie jest jasne przy tym, czy ta fragmentaryczna wiedza jest refleksją nad istniejącymi strukturami, czy wyizolowanymi koincydencjami. Należy przyznać, że czasem trafiają się wśród nich cenne innowacje. Niektórzy badacze sądzą, że problem mógłby zostać rozwiązany za pomocą metaanalizy. Jednakże metaanaliza polegająca na replikowaniu rezultatów badań przez porównanie i syntezę istniejących wyników z różnych badań oraz dokładną ocenę ich tematyki, jak np. organizational learning, nie eliminuje rozdrobnienia. Ponadto metaanaliza nie ma zastosowania w badaniach jakościowych. Nie należy więc tracić na nią, jako na substytut replikacji, środków, które i tak są ograniczone. „Porównując wiedzę zgromadzoną w kilku głównych obszarach, można wyraźnie wskazać moc wyjaśniającą teorii w odniesieniu do tych obszarów; niektóre teorie są dobre w wyjaśnianiu pewnych zjawisk, ale żadnych innych. Ułatwia to identyfikację granicy, poza którą teoria jest mało prawdopodobna. Wiedza o granicy trafności teorii jest niezmiernie istotna, gdy chodzi o jej stosowanie w praktyce" (s. 155-156).

Zagadnienie powtarzalności (replikowalności) badań jest niezmiernie istotne w tworzeniu autentycznej wiedzy naukowej. Kwestia ta wymaga większej uwagi ze strony badaczy zarządzania. W sprawie tej występują napięcia między zwolennikami rozmaitych podejść do badań naukowych. Pozytywiści są rzecznikami replikacji, a przedstawiciele wielu innych orientacji metodologicznych są jej przeciwni. Natomiast zwolennicy realizmu krytycznego starają się pogodzić stanowiska, wskazując rolę, jaką odgrywa replikacja w tworzeniu teorii. Na zakończenie rozdziału autor pisze: „Badania zarządzania rzadko są przeprowadzane w warunkach zamknięcia ${ }^{5}$, w związku z czym niepowodzenia replikacji nie należy traktować jako rozstrzygającego o fałszywości danej teorii. [...] rozwój dyscypliny zarządzania może dojść do etapu, w którym badacze muszą odpowiedzieć na takie oto pytanie: czy w procesie zachęcania do bardziej innowacyjnych badań nieopacznie bagatelizowaliśmy rolę replikacji?" (s. 157).

5 To jest ściśle określonego i ograniczonego przedmiotu badań. 


\section{Rozdział siódmy - Historiografia: zapomniana metoda badań}

Powołując się na innych autorów (Goodman, Kruger 1988, s. 315, Kieser 1994, Zaid 1993, s. 590), Tsang wskazuje historię teorii organizacji jako niemal zapomniane źródło wiedzy o działalności zorganizowanej i zarządzaniu. Zwraca uwagę na to, że kultura organizacyjna jest zakorzeniona w historii organizacji i może, i powinna, stanowić przedmiot badań wnoszący istotny wkład w wiedzę o funkcjonowaniu biznesu. Jednakże badania historyczne nie cieszą się uznaniem w debatach akademickich, historia nie jest obecna na konferencjach dotyczących nauki o zarządzaniu, tylko nieliczni wykładają historię organizacji, historia prawie nie występuje w podręcznikach z tej dziedziny. A przecież historia ma znaczenie dla rozwoju teorii zarządzania. W związku z tym w celu opisania istoty wyjaśniania historycznego autor prezentuje właściwy historii, dedukcyjno-nomologiczny model i mechanizm, z jakiego korzysta się przy wyjaśnianiu, oraz przedstawia wyjaśnianie idiograficzne i jego znaczenie dla tworzenia wiedzy nomotetycznej. Za przykład kazusu historycznego posłużyła w książce fuzja General Motors i Fisher Body w latach 1919-1926. Na końcu zestawione zostały korzyści płynące z korzystania z historiografii, czy raczej jej zasługi dla wzbogacenia wiedzy teoretycznej, zwrócono też uwagę na kontekst „,przedteoretyczny”, jakiego dostarcza historia. Porównano badania historyczne z tradycyjnymi metodami, takimi jak badanie przypadków, eksperymentowanie, analiza danych archiwalnych, i wskazano, jaki udział mają badania historyczne we wzbogacaniu skarbnicy wiedzy o zarządzaniu.

\section{Rozdział ósmy - Patrzqc w przyszłość: być albo nie być nauka}

Autor informuje czytelników, że pisał książkę z przekonaniem, że badacze zarządzania traktują swą pracę jako działalność naukową i dlatego przedstawione w publikacji rozważania metodologiczne są pochodną tego założenia. Jednakże jak pokazują przypadki - niektóre z przedstawionych badań zarządzania nie spełniają warunków umożliwiających uznanie ich za naukowe. A może badacze zarządzania wcale nie uważają swych badań za naukowe? - pyta autor książki.

Postęp w dziedzinie badań przyrodniczych spowodował wyniesienie nauki na piedestał, dlatego nowe dyscypliny, takie jak nauka o zarządzaniu, aspirują do członkostwa w „klubie Nauka”. Określenie „teoria zarządzania” brzmi lepiej aniżeli samo „zarządzanie”, szczególnie gdy stanowi przedmiot nauczania. Tsang przytacza pracę Pfeffera (1993), który powołując się w niej na wprowadzone przez Kuhna pojęcie paradygmatu, domagał się uzgodnienia w jakimś stopniu stanowisk głoszonych przez badaczy zarządzania. Spotkało się to z krytyką - uznano, że jest to warunek zbyt silny. Ale nawet postmoderniści postrzegają dyscyplinę zarządza- 
nia jako naukę, i to „naukę postmodernistyczną”, co autor książki uważa za oksymoron. Aspirowanie dyscypliny zarządzania do bycia nauką stoi w konflikcie ze stosowanymi przez badaczy zarządzania praktykami, które są odmienne od tych wykorzystywanych w naukach przyrodniczych. Inny więc powinien być argument publikowalności prac z zakresu tej dyscypliny. Prace powinny być pisane w sposób spójny, tak by wyjaśnić, co autor chce przekazać, i by zapewnić mu uznanie ze względu na wewnętrzną logikę wywodu.

Bycie nauką, a zauważmy, że w języku angielskim science to nauka ścisła, przyrodoznawcza (nature), wymaga spełniania warunków, jakie są jej przypisane. Nie spełniają ich nauki społeczne - arts w terminologii anglosaskiej. Opieranie się na analizie przypadków jednostkowych nie kwalifikuje wyników do bycia naukowymi, a takimi są z reguły badania z zakresu zarządzania. Nie jest więc prawdziwe głoszenie na wykładach z zarządzania, że jest to nauka. Jest to raczej tzw. story telling. Autor proponuje zamiast tego, żeby dyscyplina

żyła zgodnie z naukowym statusem, który stara się osiągnąć. W tym przypadku badacze zarządzania powinni przestrzegać norm dotyczących nauki. Nie trzeba dodawać, że będzie to bardzo trudne, czy nawet niemożliwe do wykonania dla subskrybentów pewnych filozoficznych perspektyw. Jak powiedziano, nauka jest budowana na realistycznej ontologii i obiektywnej epistemologii, każda z filozoficznych perspektyw, takich jak postmodernizm, która przyjmuje przeciwne ontologiczne i/albo epistemologiczne pozycje, jest prima facie niezgodna z nauką (s. 196-197).

Pomocne $\mathrm{w}$ tym mogą być zmodyfikowana polityka redakcyjna periodyku Strategic Management Journal oraz pojawienie się nowego czasopisma - Academy of Management Discoveries, „którego misją jest wspieranie badań empirycznych zarządzania i zjawisk organizacyjnych niewyjaśnianych w sposób adekwatny przez nasze teorie" (s. 197). Postęp w tej sprawie jest jednak, zdaniem Tsanga, zbyt mały i zbyt wolny. Autor książki wzywa społeczność badaczy zarządzania do otwartej, szczerej i demokratycznej dyskusji, czy dyscyplina ma być nauką (science) i stosować się do cechujących naukę norm. Jeśli nie, to może należy ją podzielić na dwa nurty - jeden naukowy, drugi swobodniejszy. Za wzór może posłużyć podział na psychologię i parapsychologię czy astronomię i astrologię (s. 197). Na tej podstawie można wnioskować, że Tsang nie darzy sympatią owego drugiego nurtu, uważa bowiem za nadużycie określanie mianem naukowej każdej z badawczych praktyk składających się na obecną chaotyczną sytuację.

Oto moja odpowiedź na apel Tsanga: zaskakujący jest brak wskazania przez niego faktu, że nauka o zarządzaniu jest nauką praktyczną - jak pisał Tadeusz Kotarbiński, czy nauką o artefaktach - jak pisał Herbert A. Simon. Ich wyróżnikiem metodologicznym jest projektowanie. Niech mi będzie wolno przytoczyć obszerny fragment mojego artykułu na ten temat: 
Metodologia nauk praktycznych, tudzież nauk o artefaktach, wskazuje p roje kto w a n i e jako wyróżnik metodologiczny tych dyscyplin. Czytamy więc u Kotarbińskiego, że projektowanie to naczelna robota dyscyplin praktycznych [Kotarbiński 1990, s. 412], a u Simona, że: „Projektuje każdy, kto kształtuje tok działania ukierunkowany na zmianę istniejących sytuacji w sytuacje preferowane. Działalność intelektualna wytwarzająca materialne artefakty nie różni się istotnie od działalności polegającej na przepisaniu środków choremu pacjentowi czy działalności związanej z opracowaniem nowego planu sprzedaży dla firmy lub polityki społecznej dla państwa. Takie projektowanie jest rdzeniem wszelkiego i profesjonalnego przygotowania; jest podstawowym wyróżnikiem profesji, odróżniającym je od nauk [podstawowych]. Zarówno szkoły inżynierskie, jak też architektoniczne, biznesu, edukacji, prawa i medycyny, są skoncentrowane na procesie projektowania" [Simon 1981, s. 129]. Zrozumiałe jest więc, że autorzy książki o projektowaniu organizacyjnym [Schlesinger i in. 1999] podkreślają kluczowe znaczenie projektowania dla pracy menedżerskiej par excellence, wiążącej się ze sztuką syntezy, ta zaś jest istotą projektowania będącego koncepcyjnym przygotowaniem działań [Gasparski 1978] [...]. Podejmują więc specjaliści z dyscyplin praktycznych operacje badawcze - obserwacje, eksperymenty, rozumowania, manipulacje - służące poznaniu. [...] „I oto te nauki, które należą do umiejętności praktycznych, różnią się wyraźnie od tych, które należą do umiejętności teoretycznych: w przypadku tych pierwszych wszystko służy przygotowaniu najsprawniejszego wykonania operacji myślowej polegającej zawsze na obmyśleniu środków do osiągnięcia celu” [Kotarbiński 2003, s. 342]. Wedle powyższego nauka organizacji i zarządzania (NOIZ) jest nauką (dyscypliną) praktyczną w takim sensie, w jakim dostarcza wiedzy mogącej służyć za przesłanki do budowy projektów stanowiących specjalność tych, którzy zawodowo zajmują się kształtowaniem organizacji. Jest to wiedza wyspecjalizowana czerpana zarówno z nauk teoretycznych, jak też z analizy wcześniej projektowanych rozwiązań i ich funkcjonowania (uwieńczonego sukcesem lub brakiem sukcesu).

Kształtowanie organizacji polega, jak wcześniej powiedziano, na nadawaniu struktury, przez co rozumie się całokształt relacji wiążących indywidua tworzące organizację (skład) oraz te indywidua $\mathrm{z}$ indywiduami spoza organizacji (otoczenie). Trójka uporządkowana: skład, otoczenie, struktura tworzą system [Bunge, 1979]. Kształtowanie organizacji stawowi istotę zarządzania; jest ono dwojakiego rodzaju: (a) uprzednie, tj. poprzedzające utworzenie organizacji, mówi się wówczas o planowaniu, (b) nadążne, $\mathrm{tj}$. $\mathrm{w}$ trakcie funkcjonowania organizacji. $\mathrm{W}$ obu przypadkach argumentem rozstrzygającym jest trafność postępowania ugruntowana poznawczo, którego dostarczają dobrze uzasadnione zdania z NOIZ. Jakie to zdania? Są to odpowiedzi na pytania związane z poszukiwaniem dwojakiego rodzaju środka do osiągnięcia celu: (a) środka obiektywnego, (b) środka subiektywnego. Środka obiektywnego poszukuje się, rozwiązując problem, któremu T. Kotarbiński [2003] nadał taką oto postać: z ajście jakiego zdarzenia wystarczy - w połączeniu z istniejącymi warunkami - do wytworzenia warunków, po których zgodnie z daną prawidłowością przebiegu zdarzeń - zajdzie zdarzenie, które jest celem danego działania. Srodka subiektywnego poszukuje się, rozwiązując problem (ibidem) o postaci: jakie oddziaływanie wywarte przez działającego na tworzywo, nad którym on pra- 
cuje, okaże się środkiem do osiągnięcia środka obiektywnego traktowanego jako cel [Gasparski 2007].

\section{Załącznik: jak filozofia wspomaga metodologię badań}

Dwa cele przyświecały autorowi książki, by zamieścić w niej załącznik. Pierwszym jest dokonanie przeglądu artykułów poświęconych metodologii zarządzania, drugim - wskazanie kierunków rozwoju tej problematyki. Tsang poddał analizie, jak pisze, 11 czasopism poświęconych zarządzaniu i organizacji i dokonał przeglądu artykułów publikowanych w nich w latach 1984-2015. Następnie zapoznał się z nimi się i stworzył listę 50 artykułów, w których przywoływane było słowo „filozofia”, wskazał przy tym kwestie metodologiczne, charakter poruszanego problemu, filozoficzną perspektywę bądź nazwisko filozofa występujące w tych artykułach. Nie korzystał z publikacji książkowych poświęconych metodologicznym aspektom zarządzania, choć niektóre wymienia w bardzo obszernych wykazach literatury cytowanej zamieszczonych na końcu poszczególnych rozdziałów. Zdaniem Tsanga zestawione artykuły wskazują na rosnące zainteresowanie środowiska badaczy zarządzania problematyką filozoficzną, co jest niezmiernie zachęcające. Skłonny jestem potwierdzić wniosek autora, ponieważ od roku 2015 wydawnictwo Springer publikuje czasopismo Philosophy of Management.

W drugiej części załącznika autor podaje wskazówki, co należałoby zrobić w przyszłych badaniach dotyczących zarządzania. Przede wszystkim niezbędne jest poszerzenie wiedzy z zakresu epistemologii, metafizyki i historii zachodniej myśli filozoficznej przez badaczy zarządzania. Niedostatek tej wiedzy był zauważalny w trakcie analizy artykułów ze wspomnianej listy 50. Badacze zarządzania niczym nie ryzykują, jeśli będą studiować literaturę odnoszącą się do problematyki metodologicznej. Mogą być nawet pozytywnie zaskoczeni. Bogata jest bowiem wiedza sprzyjająca podniesieniu jakości badań zarządzania. Autor przytacza potwierdzające to przykłady z praktyki badawczej i biznesowej. Pożyteczne jest także ponowne odczytanie wcześniejszych prac ze względu na „obserwacje ze wsparciem teoretycznym" (theory-ladennes of observation). Krytyczne myślenie jest charakterystyczne dla zachodniej filozofii. Tsang za wzór stawia Sokratesa, Platona, Arystotelesa i dodaje, że filozofowie lubią się spierać i debatować, co powoduje, że dyscyplina się rozwija. „Menedżerowie muszą się w tej sprawie wiele nauczyć od filozofów. Niestety nieliczne są debaty i rzadko nawiązywany jest dialog w tym nurcie badawczym" (s. 217-218) - pisze autor książki. Zachęca więc badaczy zarządzania do czytania artykułów na ten temat, ze szczególnym uwzględnieniem tych pisanych przez autorów korzystających z perspektywy filozoficznej. Namawia także do identyfikowania problemów i prezentowania tego, co wymaga krytyki, oraz nowych rozwiązań aktualnych problemów. „Taki intelektualny dialog uczyni dziedzinę silniejszą" (s. 217-218) - konkluduje Tsang. 
Nie ulega wątpliwości, że ta unikatowa książka powinna być przedmiotem studiów tych wszystkich, którzy poważnie traktują badania zarządzania. Nie wystarcza bowiem sama znajomość zarządzania, gdy pragnie się je badać. Niezbędna jest wiedza o samym badaniu, a więc swego rodzaju naukoznawstwie, w szczególności metodologii. Ta zaś zakorzeniona jest w filozofii jako sztuce myślenia.

\section{Bibliografia}

Bhaskar R., 1978, A Realist Theory of Science, $2^{\text {nd }}$ ed., Hassocks: Harvester Press.

Brande S. E., 1979, ESP and Psychokinesis: A Philosophical Examination, Philadelphia PA: Temple University Press.

Bunge M., 1979, “Ontology: The World of Systems”, w: M. Bunge, Treatise on Basic Philosophy, Vol. 4, Dordrecht: Reidel.

Bunge M., 1997, "Mechanism and Explanation", Philosophy of the Social Sciences 27: 410-465.

Cumming G., 2008, "Replication and $p$ Intervals: $p$ Values Predict the Future Only Vaguely, But Confidence Intervals Do Much Better", Perspectives in Psychological Science 3: 286-300.

Danermark B., Ekstr M., Jakobsen L., Karlson J. C., 2002, Explaining Society: Critical Realism in the Social Sciences, London: Routledge.

Donaldson L., 1995, American Anti-Management Theories of Organization. A Critique of Paradigm Proliferation, Cambridge: Cambridge University Press.

Dretske F. I., 1977, "Referring to Events", Midwest Studies of Philosophy 2: 90-99.

Friedman M., 1953, Essays in Positive Economics, Chicago: University of Chicago Press.

Gasparski W., 1978, Projektowanie - koncepcyjne przygotowanie dziatań: wstęp do metodologii, Warszawa: PWN.

Gasparski W., 2007, „Wiedza o organizacji i zarządzaniu oraz jej poznawcze ugruntowanie”, Wspótczesne Zarządzanie 1: 34-47.

Gasparski W. (ed.), 2018, Praxiological Essays: Texts and Contexts, seria: Praxiology: The International Annual of Practical Philosophy and Methodology, Vol. 25, New York: Routledge, Taylor and Francis Group.

Goodman R. S., Kruger E. J., 1988, "Data Dredging or Legitimate Research Method? Historiography and Its Potential for Management Research", Academy of Management Review 13: 315-325.

Hammond K., Types of Management Philosophy, https://bizfluent.com/info-8580785-types-management-philosophy.html (dostęp: 7.05.2019).

Hägg I., Hedlund G., 1979, “'Case Studies' in Accounting Research”, Accounting Organizations and Society 4(1/2): 135-143.

Hempel C. G., 1965, Aspects of Scientific Explanation and Other Essays on the Philosophy of Science, New York: Free Press.

Kieser A., 1994, "Why Organization Theory Needs Historical Analyses - and How This Should Be Performed", Organization Science 5: 608-620.

Koontz H., 1961, “The Management Theory Jungle”, Academy of Management Journal 4(3): 174-187.

Kotarbiński T., 1990, Elementy teorii poznania, logiki formalnej i metodologii nauk, w: T. Kotarbiński. Dzieła wszystkie, Wrocław: Ossolineum.

Kotarbiński T., 2003, „Znawstwo zagadnień organizacyjnych”, w: T. Kotarbiński, Dzieła wszystkie, cz. 2: Prakseologia, Wrocław: Ossolineum.

Lax E., 2004, The Mold in Dr. Florey's Coat: The Story of the Penicillin Miracle, New York: Henry Holt.

Lawson T., 1997, Economics and Reality, London: Routledge. 
Mintzberg H., 2005, "Developing Theory about the Development of Theory", w: K. G. Smith, M. A. Hitt, Great Minds in Management: The Process of Theory Development, Oxford: Oxford University Press, s. 355-372.

Mintzberg H., Ahlstrand B., Lampel I., 1998, Strategy Safari: A Guided Tour Through the Wilds of Strategic Management, New York: Free Press.

Nagel E., 1963, "Assumptions in Economic Theory”, American Economic Review 53: 211-219.

Nelder J. A., 1986, "Statistics, Science and Technology", Journal of the Royal Statistical Society, Series A 149: 109-121.

Okhuysen G., Bonardi J. P., 2011, “The Challenges of Building Theory by Combining Lenses”, Academy of Management Review 36: 6-11.

Pfeffer J., 1982, Organizations and Organization Theory, Marshfield, MA: Pitman.

Pfeffer J., 1993, "Barriers to the Advance of Organizational Science: Paradigm Development as a Dependent Variable", Academy of Management Review 18: 599-620.

Popper K., 1959, The Logic of Scientific Discovery, London: Hutchinson (wyd. polskie Logika odkrycia naukowego, thum. U. Niklas, Warszawa: PWN, 1977).

Schlesinger P. F., Sathe V., Schlesinger L. A., Kotter J., 1999, Projektowanie organizacyjne, z przedmową W. Gasparskiego, Warszawa: PWN.

Schwand T. A., 1997, Qualitative Inquiry, Thousand Oaks, CA: Sage.

Simon H. A., 1981, The Sciences of the Artificial, $2^{\text {nd }}$ ed., Cambridge, Mass.: The MIT Press.

Simon H. A., 1989, "Metodologiczne podstawy ekonomii”, thum. M. K. Mlicki, Prakseologia 4(105): 129-152.

Smith G. K., Hitt M. A. (ed.), 2005, Great Minds in Management: The Process of Theory Development, Oxford: Oxford University Press.

Strawson P. F., 1985, “Causation and Explanation”, w: B. Vermazen, M. B. Hintikka (ed.), Essays on Davidoson, Oxford: Oxford University Press, s. 115-135.

Tsang E. W. K., 2004, “Toward a Scientific Inquiry into Superstitious Business Decision-Making”, Organization Studies 25: 923-946.

Yin R. K., 2014, Case Study Research: Design and Methods, $5^{\text {th }}$ ed., Thousand Oaks CA: Sage.

Zaid M. N., 1993, "Organization Studies as a Scientific and Humanistic Enterprise: Toward a Reconceptualization of the Foundations of the Field", Organization Science 4: 513-528. 